\title{
Die wonderbaarlike vermeerdering van brood (Matt 14:13-21 en par): Historiese kritiek in perspektief
}

\author{
AG van Aarde
}

\section{Abstract}

The miraculous multiplication of loaves (Mt 14:13-21 and par): Historical criticism in perspective

Certain aspects of the historical critical method are applied to the doublet of the narration of the miraculous multiplication of loaves in the Gospels of Mark and Matthew. An offset is that a single tradition apparently lies beyond the doublet. Furthermore, that the first narrative has been moulded from out of a particularistic perspective within a Palestinian situation in early Christianity and the second from out of an universalistic perspective within ' $n$ Hellenistic situation. Thirdly, that Mark in his redactional interpretation of the narration used these perspectives for the purpose of eucharistic catechesis. Matthew, on the other hand, reinterpreted Mark's usage, fashioned the doublet into a messianic meal and emphazised more explicitly the intermediary role of the disciples in the feeding of the crowd. The article's intention is to put the historical critical method in perspective against the accusation that this method is a threat to the church and reformational theology.

... the old canard should at long last be put to rest which says that inherent in the historical-critical method itself is a denial of the miraculous ... not the historical-critical method as such but the doctrine of God to which the individual interpreter subscribes is what dictates whether he will be open or not to the possibility of miracle (Kingsbury 1975: 140).

'n Teologie wat ... sy eie refleksie as 'n kritiese verantwoording oor die inhoud van die Christelike geloofstradisie wil sien, bedreig geensins die geloofsekerheid van gelowige mense deur sy kritiese instelling nie, maar help veel eerder ... om die vrae en onsekerhede wat in die geloofsbelewenis van 'n gemeenskap mag leef, bewustelik tot tema te maak (Van Huyssteen 1986: 185).

- Referaat gelewer voor die Suider-Afrikaanse Bybelkundevereniging op 2 Mei 1986, RAU, Johannesburg 


\section{INLEIDING EN VRAAGSTELLING}

Die negatiewe veroordeling van die historiese kritiek het deur die jare 'n refrein gekry, naamlik dat dit as eksegetiese benadering onversoenbaar met die aard van die Heilige Skrif is en daarom nie aan die waarheid van die Heilige Skrif reg laat geskied nie.

Deur aspekte van die historiese kritiek toe te pas op die vertelling oor die vermeerdering van brood (Matt 14:13-21 en par), poog ek om die histories-kritiese (metodologiese) vraagstelling in perspektief te plaas en tweedens te illustreer dat 'n bepaalde vraagstelling bepaalde antwoorde kan verwag. Hiermee word die ongeldigheid van bogenoemde oordeel aan die kaak gestel. Dit vermeng naamlik metodologiese kwessies met teologiese. 'Eksegese' behoort egter in 'teologie' uit te mond. Maar die eiesoortigheid van elkeen se vraagstellings en ooreenkomstige resultate moet van mekaar onderskei word. Dieter Lührmann het onlangs ' $n$ behartenswaardige bydrae ten opsigte van die eksegetiese metodologie gemaak. Hy beklemtoon dit dat enige toepassing van 'n metode op die Bybel geloofsverantwoordende implikasies het: '... Exegese (ist) schliesslich als solche ein theologisches Programm' (Lührmann 1984: 28). Tog is dit heeltemal onnodig om soos Lührmann 'n weersin van 'metodes' te hê en is dit nie korrek om sy voorstel te aanvaar wat die term 'metodologiese vraagstellings' met 'teologiese vraagstellings' wil vervang nie.

Ek self is krities ten opsigte van die historiese kritiek. Konstruktief sal ek probeer om die moontlikhede sowel as die tekortkominge van die historiese kritiek met betrekking tot die aard en die waarheid van die Heilige Skrif aan die orde te stel. My tese is dat om die historiese kritiek as die oorsaak van die rasionalistiese en skeptiese historisiteitvraagstelling van die Aufklärung en die post-Aufklärung te beskou, 'n oorvereenvoudiging van die betrokke eksegeties-metodologiese en teologiese probleme is. Die historiese kritiek is 'eerder 'n poging ... om die reeds bestaande probleem (teksteoreties en teologies - AG v A) te hanteer' (Schnell 1986).

Die referaat val naas die inleiding in vier hoofdele uiteen. Eerstens, die historiese kritiek word eksegeties-metodologies, kenteoreties en geloofsverantwoordend in perspektief geplaas. Tweedens, form- en traditionsgeschichtliche en, derdens, redaktionsgeschichtliche vrae word aan Matteus 14:13-21 en parallelle tekste gestel. Vierdens, nabetragtend word daar baie kortliks na die vraagstelling hierbo teruggekeer. 


\section{DIE HISTORIESE KRITIEK IN PERSPEKTIEF}

\section{1 'n Verpligting tot rasionaliteit}

\subsubsection{Genetiese verklaringswyse}

Die historiese kritiek het ' $n$ verpligting tot rasionaliteit. Dit is egter alleen in ' $n$ sekere sin dat sy basis terug te vind is in die wêreld van die sewentiende- en agtiende-eeuse rasionalisme. Om die oorsprong en wording van tekste te ondersoek is nie 'n onredelike aktiwiteit nie. Enige kritiese verantwoording het 'n verpligting tot rasionaliteit. Tog is die rasionalisme as sodanig nie die uitgangspunt van en samebindende element tussen die onderskeie metodiese fasette van die historiese kritiek as eksegetiese benadering nie. Dit is veeleer die genetiese verklaringswyse wat ten grondslag van die histories-kritiese eksegese lê (kyk Lategan 1982: 58). Volgens die genetiese verklaringswyse is die terugvind van die oorsprong en ontwikkeling van verskynsels tegelykertyd die verklaring daarvan. Sowel die moontlikhede as tekortkominge van die historiese kritiek as 'n eksegetiese benadering kom uit hierdie vooronderstelling voort. In só 'n verklaringswyse is die evolusionêre wording van 'n teks en die invloed van die skrywer op die inhoud daarvan die objek van die ondersoek (kyk Vorster 1982: 94).

\subsubsection{Rasionalisme?}

Dit is nie korrek om die historiese kritiek en die rasionalisme sonder meer met mekaar gelyk te stel en die historiese kritiek derhalwe af te maak as 'n eksegetiese benadering wat summier Skrif-vyandig, kerkvyandig, dogma-vyandig, geloof-vyandig, ensovoorts sou wees nie. So 'n negatiewe ingesteldheid kom veral in die teologiese en kerklike kringe van sowel die ortodoksie as die piëtisme voor. Dit word ook deur sommige beoefenaars van die historiese kritiek self met hulle teologiese toepassings gestimuleer. Wie op die 'rede' vertrou, verlaat die pad van die 'geloof', word dikwels deur die ortodoksie geleer. As die term 'rede' egter met 'wetenskap' omgeruil sou word, dan besef ons dat 'rede' nie noodwendig Bybel-vyandig is, die dogmatiese teologie wil vervang met ' $n$ verstandsteologie of selfs die 'geloof' wil uitban nie.

Daar is genoeg bewyse van gelowiges in die periode van die Aufklärung self en daarna wat voluit histories-krities die Bybel uitgelê het en die dogmatiese teologie en die kérk gedien het. Negatiewe kritiek lê te veel klem op uiterstes, soos op sekere beoefenaars van die historiese 
kritiek wat byvoorbeeld die opstanding van Jesus rasionalisties en historisties benader. Die agtiende-negentiende-eeuse Nuwe-Testamentikus, WEG Paulus, is só 'n eksponent van die historiese kritiek. $\mathrm{Hy}$ is bekend vir sy radikale uitsprake in verband met Jesus se opstanding uit die dood (kyk Schweitzer 1951). Inderdaad laat hy 'n onreg aan die aard en die gesag van die Bybel geskied. Maar radikale standpunte soos dié van WEG Paulus word te maklik veralgemeen as dié historiese kritiek. Aan die ander kant word die positiewe en baanbrekende bydraes, van byvoorbeeld JP Gabler aan die einde van die agtiende eeu (kyk Boers 1979: 23-39), nie genoegsaam gewaardeer nie. Gesonde verdraagsaamheid het nog altyd die kerk en die Bybelwetenskap gedien en nie ondermyn nie. Ons sou sonder die historiese kritiek baie armer gewees het.

\subsubsection{Die Reformasie}

Hoewel sommige teoloë dit ontken (bv deur Zorn 1984 en by implikasie deur Fryer 1984 en [1986]), kan 'n sterk saak daarvoor uitgemaak word dat die historiese kritiek 'n voortsetting en verdieping is van die histories-grammatiese/letterlike eksegetiese benadering vanuit die periode van die Reformasie. Myns insiens is die histories-kritiese benadering nie 'n afvallige kind van die Reformasie nie. Dit is een van die Reformasie se waardevolle erfstukke.

Dit is dus logies dat die histories-kritikus dikwels resultate van 'n histories-grammatiese uitleg kan benut en verder eksploiteer. Hoewel 'n eksegetiese metode agterhaal kan raak, bly heelwat van die resultate daarvan betekenisvol. Dit geld natuurlik nie net die histories-grammatiese metode nie, maar ook resultate van die allegoriese eksegese vanuit die Middeleeue sowel as van die histories-kritiese eksegese vanuit die Verligting. So is daar, wat die vertelling oor die vermeerdering van brood betref, merkwaardige raakpunte tussen die resultate van die eksegese deur Augustinus (kyk Boobyer 1953: 77), Richardson (1955: 146) en Schmidt [1919] (1969: 172-214).

\subsection{Wat is die historiese kritiek?}

Ter wille van duideliker uiteensetting onderskei ons tussen drie sake: metodologie, werkwyse en benaderingwyse. 


\subsubsection{Benaderingwyse}

E Troeltsch het die historiese kritiek beskryf as krities, analogies en korrelerend. Krentz (1975: 55) omskryf hierdie tiperinge soos volg:

* Die historiese kritiek is krities, met ander woorde metodetwyfelend, omdat daar op historiese gebied slegs waarskynlikheidsoordele gevel kan word, want niks is histories gesien volledig seker nie.

* Die historiese kritiek is analogies, omdat daar op 'n vergelykende wyse met bronne omgegaan word; met ander woorde, as die betroubaarheid van 'n gebeure aanvaar word, beteken dit dat iets soortgelyk elders (nie noodwendig 'identies' nie) gebeur het.

* Die historiese kritiek is korrelerend, omdat dié benaderingwyse op grond van die uitgangspunt dat daar ' $n$ wisselwerking tussen verskynsels moet bestaan, na die verband tussen gebeure soek, in die sin van byvoorbeeld oorsaak-gevolg.

\subsubsection{Werkwyse}

In die lig van bogenoemde benaderingwyse, en terugskouend op die werk van histories-kritici, beskryf De Jonge (1982: 78) die werkwyse van die historiese kritiek soos volg:

* Dit gaan analities te werk.

* Dit soek na tekens wat daarop sou dui dat die teks nie 'n integrerende eenheid is nie.

* Dit tabuleer verskille in woordkeuse, grammatika en styl, teenstrydighede in inhoud, doeblette, ensovoorts.

* Dit probeer die teks verklaar in terme van teksgeskiedenis en -kritiek, kultuurhistoriese en godsdienshistoriese agtergrond, bronne, formeel- en inhoudelik-verwante tekssoorte, mondelinge en literêre oorleweringsgeskiedenis, redaksionele verwerkings, ensovoorts.

\subsubsection{Metodologie}

Die historiese kritiek het met verloop van tyd in drie (vier?) duidelik onderskeibare (hoewel nie geskeie nie) metodes van eksegese uiteengeval, naamlik Literarkritik, Traditions- en Formgeschichte en Redaktionsgeschichte. Hierdie verskillende metodiese aspekte van die historiese kritiek kom onderling die een uit die ander na vore en oorvleuel derhalwe dikwels op mekaar se terrein. Histories-kritiese 
eksegese hou egter nie in dat daar in volgorde vanaf Literarkritik tot by Redaktionsgeschichte gewerk moet word asof daar op so 'n metodepluralistiese wyse deurgedring kan word tot die teks se betekenis nie. Verskillende antwoorde op respektiewelik verskillende vrae word met behulp van respektiewelik verskillende metodes verkry. Wat die Nuwe Testament, en in die besonder die evangelies betref, het die Literarkritik die outeur se aanwending van bronne in die oog, byvoorbeeld die skrywer van die Matteusevangelie wat van die Markusevangelie as belangrikste bron gebruik gemaak het. Die Traditions- en Formgeschichte plaas die klem op die analise van oorleweringstadia, die korrelerende sosiologiese situasies in die vroeë kerk en die uitwerking wat dit op die seleksie, omvorming en herinterpretasies van onder andere Jesus-woordtradisies gehad het. Die Redaktionsgeschichte worstel met vrae oor die aard van die invloed van die Bybelskrywer, as redaktor en as vertolker van 'n spesifieke teologiese perspektief in ' $n$ bepaalde vroeg-kerklike gemeentekring, op die redaksionele redigering van oorgelewerde Jesus-tradisies binne 'n makroteks, byvoorbeeld die Matteusevangelie as geheel.

\subsection{Moontlikhede en tekortkominge}

\subsubsection{Afstand tussen eksegeet en teks}

Die historiese kritiek kan ook gesien word as 'n kenteoretiese aangeleentheid. As 'n epistemologiese paradigma (met betrekking tot die term 'paradigma', kyk Van Huyssteen 1986: 63-87) staan die historiese kritiek teenoor 'n Platonies-ideële denkskema (kyk Deist 1984). Laasgenoemde kenteorie dra in homself die kiem van die mees verleidelike dwaling wat daar in die verlede en ook in die hede met betrekking tot die hermeneutiek van die Bybel bestaan. Dit is naamlik die dwaling van misplaaste konkreetheid (kyk Van Aarde 1985: 568-571).

Die feit dat die verstaan van die Bybel altyd tegelykertyd toepassing in die hede veronderstel, kom daarop neer dat daar 'n brug tussen twee tye gebou is: die historiese tyd van die Bybel en die teenswoordige tyd van die eksegeet. Rudolf Bultmann het hiervanuit dié interrelasie Verstehen en Glauben genoem. Maar as die bestaan van die distansie wat in die verstaansproses oorbrug word, nie kenteoreties en eksegeties-metodologies in ag geneem word nie, kan ons met misplaaste konkreetheid te make hê. Dis waarom die histories-letterlike eksegese vandag nie meer oortuig nie. Hierdie paradigma laat nie die afstand tussen die 
teenswoordige eksegeet en die historiese Bybel metodologies toereikend genoeg oorbrug nie. Afgesien van die subjektiwisme wat hieruit kan voortspruit, veroorsaak so 'n benadering 'n Skrifgebruik wat vreemd is aan die grondliggende intensie van die Reformasie.

Die ontstaan en voortbestaan van die gereformeerde skolastiek sedert die sewentiende eeu is ironies 'n vervreemdende uitwerking van die Reformasie. Daarenteen het die historiese kritiek bygedra dat die nodige afstand tussen eksegeet en die Bybel geskep is. Die Reformasie het die amptelike kerklike oordeel as norma normata (afgeleide, sekondêre gesag) teenoor die Skrif self as norma normans (primêre gesag) waardeer. Daarmee is die summiere gelykstelling tussen die Bybel en die kontemporêre kerklike denke of eksegese afgewys. Die historiese afstand daartussen is inteendeel benadruk. Boers (1979: 17) formuleer hierdie aangeleentheid soos volg:

The Bible was no longer an integral, contemporary part of the living religion but was separated from it by intervening history, that very history of the ongoing life of the church which had previously provided continuity with the Bible. A historical consciousness thus arose with the Reformation. This was not immediately recognized, but it was only a question of time before it began to become clear, and historical criticism would emerge (my beklemtoning).

Die Middeleeuse skolastiek vóór die Reformasie het nie met so 'n historiese bewussyn die Skrif gebruik nie. Dit kan onder andere ook in die Middeleeuse kunswerke gesien word. Bybelse tonele is aangebied teen kontemporêre agtergrond en Bybelse karakters is met kontemporêre kleredrag aangetrek. Kontemporêre persone is selfs saam met dié van die Bybel laat optree. In 'n sekere sin kom hierdie selfde tipe vermenging van tye voor in die kerklike dogma en in die kerklike verkondiging. Die Reformasie het ons egter bewus gemaak van die gevaar van subjektiwisme waarop dié tipe konkretisering kan uitloop. Die eis van die sola Scriptura-beginsel en die hermeneutiese werkwyse Sacra Scriptura sui ipsius interpres is trouens teen die agtergrond van dié kritiese historiese bewussyn gebore. Na die Reformasie (soos ook later deur die Rooms-Katolieke Kerk erken - kyk Küng 1980: 510-514) behoort die hermeneut nie meer tekste en dogmas te eksegetiseer sonder dat hy bewustelik met die moontlikheid van misplaaste konkreetheid rekening hou nie. Die bydrae wat die historiese kritiek in hierdie verband gelewer het, behoort dus waardeer te word. Die neo-skolastiek sedert 
die sewentiende eeu in sowel die gereformeerde as Rooms-Katolieke wêreld en in die fundamentalisme van ons dag wil dié waarde van die historiese kritiek egter nie erken nie. Maar dit is hoe dit in paradigmavorming en -verandering gaan:

Revolution in science occurs when scientists find the old paradigm increasingly inadequate to cope with anomalies, and some become converted to a new paradigm, though theses under the old continue to proliferate (Montague 1979: 5).

\subsection{2 'n Element in die eksegetiese proses}

Die historiese kritiek maak nie die totale eksegetiese proses uit nie. Tog is dit essensieel in dié proses:

Important as they are, historical-critical tools are not the only ones essential for biblical interpretation ... texts from the past must be interpreted in terms of their historical meaning - what they said in and to their own times - as at least one step essential to their understanding (Tucker 1975: vi).

Vanuit ' $n$ bepaalde boek beskou, is dit selfs moontlik om op nie-fundamentalistiese oorweginge die historiese kritiek as 'n illegitieme vraagstelling in die eksegese van bepaalde Bybelse literatuursoorte, soos die evangelies, te reken (kyk Frye 1971). As verhalende literatuur is die stof in die evangelies tematies gerangskik en nie histories, kousaal-chronologies nie. Die evangelies is derhalwe metahistoriese literatuur. Om historiese 'presiesheid' in 'n teks soos 'n evangelie te verwag, is om dit verkeerd te verstaan. As verteltekste staan die evangelies los van hulle historiese skrywers. In die interpretasie van verteltekste gaan dit daarom nie soseer om die deurdring na die werklike wêreld van die historiese skrywer, plek en omstandighede van ontvangs nie. Dit gaan ook nie soseer om die beskrywing van die vroeë skriftelike of voorskriftelike kontekstualiserings van tradisies nie.

Die evangelies, gesien as vertellinge, is egter nie produkte van die verbeelding nie. Met behulp van onder andere oorgelewerde tradisies, op 'n selekterende, omvormende en herinterpreterende wyse redaksioneel verwerk, kommunikeer 'n evangelis as redaktor-verteller sy eiesoortige teologiese perspektief. 'n Histories-kritiese ondersoek na die aanwending van tradisies in 'n vertelteks kan daarom nie irrelevant wees nie. Vrae rakende tekste se bronne, tradisie-oorlewering, redak- 
siegeskiedenis, ensovoorts sal ten minste plek moet kry by inleidingswetenskaplike kwessies, soos dié na outeurskap, oorspronklike leserskring, ensovoorts (kyk Culpepper 1984: 474). Kennis hiervan sal sorg kan dra dat die eksegeet nie naief met die Bybel omgaan nie. En afgesien hiervan, die studie van die redaksionele aktiwiteit van skrywers behoort deel te wees van die eksegese van tekste met 'n evolusionêre wordingsgeskiedenis, soos die evangelies. Immers, hoe sal die teologiese motief wat geleë is agter die herrangskikking, wysiging, eliminering, uitbreiding, verkorting, ensovoorts van tradisies anders deur die eksegeet bepaal kan word? Daarbenewens het 'n evangelie nie in 'n vakuum ontstaan nie. Dit verwys na 'n situasionele konteks wat die sosio-politiese, ekonomiese en godsdienstige omstandighede van die tyd insluit. Hierdie situasionele konteks moet gerekonstrueer word. Aspekte daarvan kan nader omlyn word deur op 'n histories-kritiese wyse onder andere tekste met mekaar te vergelyk. Die kanon is so gesien saam met nie-kanonieke geskrifte volledig aan die historiese ondersoek onderwerp, terwyl die eksegeet, teologies gesien, die opmerking van Funk (1966: 11) in ag neem: "The word of God ... is not on trial.'

\subsubsection{Historiese kritiek en die aard van geloof}

Stuhlmacher (1979: 220) oefen kritiek op die historiese kritiek uit omdat dit as ' $n$ histories-rasionele onderneming maar net waarskynlikheidsoordele kan vel en nie histories-egte sekerhede kan bied nie. Hy het veral ' $n$ probleem met die so genoemde analogie-prinsiep van die historiese kritiek. Ons het reeds vroeër daarop gewys (afdeling 2.2.1) dat die waarskynlike betroubaarheid van 'n gebeure volgens hierdie vooronderstelling slegs aanvaar word as iets soortgelyk elders gebeur het. Die historiese kritiek maak dus nie voorsiening vir die unieke en die analogielose in religieuse tekste nie. Die betroubaarheid van die wonder van God se omgaan met die mens kom derhalwe in gedrang. Krentz (1975: 4) bewoord hierdie beswaar soos volg:

Scholars must ask whether historical criticism, a legacy of historicism and its philosophic presuppositions, is adequate for the investigation of the Bible .... . Can it do justice to the inner meaning of religious literature?

In antwoord op hierdie vraag moet ons die belargrike uitgangspunt hierbo (afdeling 1) in gedagte hou, naamlik dat die eiesoortigheid van 
onderskeidelik eksegetiese en teologiese vraagstellings van mekaar onderskei moet word. Wanneer die resultaat van die historiese kritiek dat ons in die evangelies nie met bruta facta te doen het nie, maar met omvormde en geïterpreteerde Jesus-woordtradisies, verder gevoer word sodat dit 'n geloofsverantwoordende kwessie word, kom ons by die teologie uit. En dis nou eenmaal nie waar dat ' $n$ erkenning van bogenoemde resultaat die historisiteit of wonder van God se omgaan met die mens ontken nie. Dit maak ook nie die belydenis van geloof onmoontlik nie.

Wat die verhouding tussen die aard van geloof en historiese betroubaarheid betref, kan die volgende opmerking van Krentz (1975: 32) as antwoord dien op sy vraag wat hierbo aangehaal is:

Barth's call raised anew the question of the relationship of faith to historical method ... Rudolf Bultmann also recognized the poverty of a historicist approach to the New Testament. He shared with Barth a concern for the Word's claim on man and sought to use historical criticism to serve that claim .... . Faith is the decision made in response to that call. Faith is not dependent on historical knowledge. Criticism can be ruthlessly practised, because it makes the nature of faith clear (my beklemtoning).

Vanuit hierdie perspektief is dit nie nodig dat daar 'n spanning tussen geloof en historiese kritiek hoef te bestaan nie. Wanneer kritiese refleksie op die Bybel in die naam van die belydenis van geloof teëgestaan en onderdruk word, is dit ' $n$ aanduiding van 'n eng en beangste geloof wat pretendeer om sterk te wees, maar eintlik bevange is (kyk ook Ebeling 1981: 12). Geloof het sy oorsprong in God. Geloof is nie gegrond op metodologiese en ander wetenskaplike bewysvoeringe nie.

\section{MATTEUS 14:13-21 (EN PARALLELLE DELE) EN DIE TRADITIONS- EN FORMGESCHICHTE}

\subsection{Wat is Traditions- en Formgeschichte?}

Hoewel die Traditions- en Formgeschichte in der waarheid twee onderskeie metodes is, word dit vir die onderhawige doel gesamentlik hanteer. Dit gaan van die standpunt uit dat ons moet aanvaar dat die tradisies van en aangaande Jesus eers mondeling oorgelewer is voordat dit op skrif gestel is. 
Die traditionsgeschichtliche eksegese is geïnteresseerd in die preliterêre stadium, dit wil sê die voor-op-skrif-stadia. Hierdie stadia strek breedweg gesien vanaf die historiese Jesus via die Arameessprekende/ Palestynse Joods-Christelike tradisiekring tot en met die heidenChristendom. Wie in byvoorbeeld die historiese Jesus of sy prediking geïnteresseerd is, sal met behulp van ' $n$ traditionsgeschichtliche ondersoek deur die verskillende kontekstualiserings op die verskillende tradisielae probeer deurdring tot by die kontekstualiseringsvlak in die lewe van die historiese Jesus. Die Formgeschichte spits hom in hoofsaak op die tweede kontekstualiseringsvlak toe en die Redaktionsgeschichte op die derde. Die tweede is dié in die.vroeë kerk voordat die evangelies, soos dit voor ons lê, op skrif gestel is. Die derde kontekstualiseringsvlak is die spesifieke vroeg-kerklike gemeentekring waarvoor en van waaruit die verskillende evangeliste as respektiewelik vertolkers van 'n bepaalde 'teologie' skryf.

Benewens die feit dat die evangelies produkte van 'n mondelinge oorleweringsproses is, bestaan die teksteorie grondliggend aan die Formgeschichte verder daaruit dat daar ' $\mathrm{n}$ bepaalde oorsaaklike verband tussen die mondelinge tradisie en die geskrewe teks bestaan. Dit kom daarop neer dat daar ' $n$ genetiese verband veronderstel word tussen die vorm (=Form/Gattung) waarin 'n tradisie gegiet is en die sosiale milieu (= Sitz im Leben) waarin dit gefunksioneer het. Gedurende die mondelinge stadium het tradisies sekere vorme aangeneem na gelang van die aard van die funksie wat dit in die vroeg-kerklike gemeenskap gehad het. Die situasie in die alledaagse lewe (Sitz im Leben) binne die vroeë kerk, byvoorbeeld die missionêre verkondiging van die evangelieboodskap, die vroeg-Christelike erediens en die vroeg-Christelike kategese, het veroorsaak dat die tradisies dienooreenkomstig funksionele vorme aangeneem het.

So byvoorbeeld het die Nuwe-Testamentiese wondervertelling sy bepaalde vorm aangeneem na aanleiding van die funksie wat dit in die vroeë kerk gehad het. Hiervolgens het dit nie 'n binne-kerklike gerigtheid, soos die prediking/kategese of die liturgie, gehad nie. Dit het eerder 'n buite-kerklike, propagandistiese funksie gehad. Die sosiale milieu waarin die wondervertelling gevorm is, sou dan die Joods-Hellenistiese en heiden-Hellenistiese gemeentelike situasies wees waar Jesus se mag oor mededingende gode en wonderdoeners beklemtoon is (kyk Dibelius 1959: 76-78).

Verskillende kriteria is al aangewend om die verskillende tipes wondervertellinge in die evangelies te klassifiseer (kyk o a Betz \& Grimm 
1977: 6). Een klassifikasiewyse geskied na aanleiding van die objek van die wonder, naamlik òf die mens ò die natuur. 'n Ander geskied na aanleiding van die dinamiek van die gebeure, naamlik genesing, redding, straf, epifanie, bewysvoering van mag, ensovoorts. Theissen (1974: $111-114 ; 114-120)$ onderskei, benewens tussen duiweluitdrywings en genesingwonders, ook tussen 'Geschenkwunder' ('gawewonders') en 'Normenwunder'. Laasgenoemde is vergelykbaar met die strydgesprekke tussen Jesus en die Joodse leiers. Die wonder funksioneer as ' $n$ legitimering dat Jesus in die strydgesprek reg is. Die wonderbaarlike vermeerdering van brood word, wat die Sinoptiese Evangelies betref en oppervlakkig gesien, onder die 'Geschenkwunder' geklassifiseer, maar word in die Johannesevangelie met die tipiese 'Normenwunder' gemeng.

Martin Dibelius, een van die pioniers in die beoefening van die Formgeschichte en wat met betrekking tot die wondervertelling uitgaan van die genoemde Sitz im Leben hierbo, onderverdeel die wondervertelling (hy noem dit 'novelle') in vertellings oor duiweluitdrywings, genesingwonders en natuurwonders. Die 'novelle' vertoon volgens Dibelius (1959: 67; vgl ook bl 73-74) die volgende basiese patroon:

* 'n Beskrywing van die 'ongesteldheid' of die situasie wat 'herstel' moet word deur ' $n$ implisiete of eksplisiete hulproep in 'n noodsituasie.

* 'n Jesus-woord wat die genesing of oplossing van die probleem teweegbring.

* 'n Uiteensetting van die resultate van die wonderwerk, naamlik òf die effek by die geneesde persoon ò die reaksie van die omstanders.

Wat die dubbel-vertelling oor die wonderbaarlike vermeerdering van brood in onderskeidelik Matteus 14:13-21 en 15:32-38 betref, kan onder andere die volgende traditions- en formgeschichtliche vrae gestel word: Kan die dubbel-vertelling as 'n 'wondervertelling' geklassifiseer word; met ander woorde kom dit met bogenoemde formele patroon ooreen? Was dit aanvanklik één gebeurtenis wat as 'n doeblet oorgelewer is? Of moet ons aanvaar dat Markus en Matteus (dié twee evangeliste wat die dubbel-vertelling opgeneem het) twee vertellinge wat werklik afsonderlik en feitlik identies pla asgevind het, oorvertel, terwyl Lukas en Johannes, weer, net één van dié twee gebeurtenisse oorvertel het? Ons gaan vervolgens kyk watter tipe antwoorde 'n traditions- en formgeschichtliche ondersoek op hierdie twee vrae bied. 


\subsection{Die wonderbaarlike vermeerdering van brood: Een of twee gebeurtenisse?}

Die dubbel-vertelling is vanuit 'n genetiese perspektief nie direk met mekaar in die Matteusevangelie gekoppel nie. Dit laat Gerhardsson (1979: 56) vermoed dat ons met twee variasies van een en dieselfde tradisie te doen het. Matteus het wel meer as Markus, die twee vertellinge met mekaar laat ooreenstem:

Toe Jesus dit hoor, het Hy met 'n skuit daarvandaan weggegaan na 'n stil plek om alleen te wees. Die mense het hiervan gehoor en Hom van die dorpe af te voet gevolg. Toe Hy uit die skuit klim, het $\mathrm{Hy}$ die groot menigte mense daar gesien. Hy het hulle innig jammer gekry en die siekes onder hulle gesond gemaak. Toe dit al aand begin word, het sy dissipels vir Hom kom sê: 'Dit is 'n afgeleë plek en dit het al laat geword. Stuur die mense terug dat hulle vir hulle kan gaan kos koop in die dorpe.' Maar Jesus sê vir hulle: 'Hulle hoef nie weg te gaan nie. Gee julle vir hulle iets om te eet.' Hulle sê toe vir Hom: 'Ons het hier net vyf brode en twee visse.' 'Bring dit vir My hier', sê $\mathrm{Hy}$. Hy het die menigte beveel om op die groen gras te gaan sit om te eet. Toe neem Hy die vyf brode en die twee visse, kyk op na die hemel en vra die seën. Daarna het Hy die brood gebreek en dit aan sy dissipels gegee, en hulle het dit aan die mense gegee. Al die mense het geëet en genoeg gekry, en hulle het nog twaalf mandjies vol bymekaargemaak van die stukke brood wat oorgebly het. Daar was omtrent vyfduisend mans wat geëet het, afgesien van die vrouens en kinders (NAB; Matt 14:13-21).

Jesus het sy dissipels nader geroep en vir hulle gesê: 'Ek kry hierdie mense innig jammer, want hulle is nou al drie dae lank hier by My en hulle het niks om te eet nie. En Ek wil hulle ook nie sonder kos huis toe stuur nie, want hulle kan miskien op pad beswyk.' Sy dissipels sê vir Hom: 'Waar sal ons in hierdie verlate plek genoeg brood kry om so baie mense kos te gee?' 'Hoeveel brood het julle?' vra Hy hulle. 'Sewe', antwoord hulle, 'en 'n paar vissies'. Hy het gesê die mense moet op die grond gaan sit. Toe neem Hy die sewe brode en die visse en dank God daarvoor. Daarna het Hy die brood gebreek en dit aan die mense gegee. Almal het geëet en genoeg gekry. En die dissipels het nog sewe mandjies vol bymekaargemaak van die stukke wat oorgebly het. 
Daar was vierduisend mans wat geëet het, afgesien van die vrouens en kinders (NAB; Matt 15:32-38).

Beide vertellinge het 'n inisiërende aanloop wat vertel hoedat die skare honger begin word het. Hulle was naamlik 'n lang tyd saam met Jesus op 'n 'afgeleë plek' (erēmon tópon). Die afloop van die twee onderskeie vertellinge is insgelyks in feitlik identiese bewoording vertel. Albei vertellinge maak melding daarvan dat Jesus uitdruklik aan die dissipels opdrag gee om vir die skare iets te gee om te eet: Die skare hoef nie weg te gaan om self kos vir hulle te gaan koop nie; die dissipels moet vir hulle kos gee, want Jesus het hulle innig lief.

In vergelyking met Markus is die vermelding van die visse in beide vertellinge tot ' $n$ minimum verminder. Die wonder self word in geeneen van die twee doeblette beskryf nie. Niks word gesuggereer dat òf die skare òf die dissipels bewus was dat 'n wonder besig is om plaas te vind nie. Die vermelding van die enersyds twaalf mandjies en andersyds sewe mandjies wat volgemak is met die stukke brood (en vis?) wat oorgebly het, impliseer wel die grootsheid van die wonder. Afgesien van die onderskeid in die getal mandjies, is die verskil in die getal mans (naas die onbepaalde aantal vrouens en kinders) wat gevoed is, opvallend: Vyfduisend teenoor vierduisend. Die enigste ander opsigtelike verskil tussen die twee vertellinge in die doeblet is dat dit die dissipels was wat in die eerste vertelling die skare se honger opgehaal het, terwyl dit Jesus was wat in die tweede vertelling die inisiatief geneem het.

Gerhardsson (1979: 27) beredeneer sy standpunt dat die twee vertellinge ' $n$ doeblet van een en dieselfde tradisie is deur die drie weergawes van die aanloop tot die vertelling in die onderskeie drie Sinoptiese Evangelies met mekaar te vergelyk. Die drie evangelies teken die omstandighede rondom Jesus se teenwoordigheid op dié afgeleë plek verskillend:

Markus vertel:

Toe Jesus uit die skuit klim, het Hy 'n groot menigte mense daar gesien en Hy het hulle innig jammer gekry, want hulle was soos skape wat nie 'n wagter het nie. Hy het hulle toe baie uitvoerig begin leer (didáskein) (NAB; Mark 6:34). 


\section{Lukas vertel:}

Hy het hulle verwelkom en met hulle gepraat oor die koninkryk van God, en dié wat genesing nodig gehad het, het $\mathrm{Hy}$ gesond gemaak (iâto) (NAB; Luk 9:11).

\section{Matteus vertel:}

Toe $\mathrm{Hy}$ uit die skuit klim, het $\mathrm{Hy}$ die groot menigte mense daar gesien. Hy het hulle innig jammer gekry en die siekes onder hulle gesond gemaak (etherápeusen) (NAB; Matt 14:14).

Dit lyk dus of Matteus ' $n$ doeblet van dieselfde gebeurtenis in sy bronne, die Markusevangelie en $Q$, teëgekom het en dat hy die weergawes van die twee bronne met mekaar geïntegreer het. Hy het dit belangrik geag om nie van die onderwysing (didáskein) waaroor Markus en $Q$ berig het, oor te vertel nie. Matteus lê, wat die skare betref, klem op Jesus se genesingaktiwiteit. Dis opvallend, want Jesus se onderrig word elders in die Matteusevangelie sterk benadruk en dit word ook in sekere opsommingsberigte neweskikkend saam met Jesus se genesingen verkondigingsaktiwiteit vermeld (kyk Matt 4:23 en 9:35).

Hoe moet die verskynsel dan verklaar word dat Markus ook die doeblet ken, terwyl hy volgens die twee bronne-teorie nie van $Q$ afhanklik sou wees nie? Van Iersel (1964: 178-179) beantwoord hierdie vraag deur die volgende (onderstreepte) bewoording in onderskeidelik Markus 6:41 en Markus 8:6 as die kernformule van 'n gemeenskaplike tradisie te beskou:

Toe het Hy die vyf brode en die twee visse geneem (kaì ... labōn), na die hemel opgekyk en die seën gevra (eulógèsen ...). Daarna het Hy die brood gebreek (kaì katéklasen ...) en dit vir sy dissipels gegee (kaì edidou tô̂s mathētaî́s ...) om aan die mense (autoîs) voor te sit (NAB; Mark 6:41).

Nadat Hy die sewe brode geneem (kaì ... labōn ...) en God gedank het (eucharistēsas ...), het Hy dit gebreek (eklasen) en vir sy dissipels gegee (kai edídou toîs mathētaîs) om uit te deel, en hulle het dit aan die mense (.. tōo ochlō) voorgesit (NAB; Mark 8:6).

Die variasie in die bewoording, ' $\mathrm{Hy}$ het die seën gevra en die brood gebreek' (eulógēsen kaì katéklasen) (Mark 6:41) en 'Nadat Hy gedank het, het Hy dit gebreek' (eucharistēsas eklasen) (Mark 8:6), beskou Van Iersel as van wesenlike belang. As saam met die meeste ondersoekers aan- 
vaar sou word dat ons in hierdie 'kernformule' 'n toespeling het op die vroeg-kerklike nagmaalsviering (kyk Gerhardsson 1979: 56-57), is dit op grond van 'n vergelyking met die ooreenstemmende bewoording in die Markus-versie van die instelling van die nagmaal (Mark 14:22) duidelik dat dit nie Markus kon wees wat die bewoording in die dubbel-vertelling met dié van die instellingswoorde laat ooreenkom het nie.

Terwyl hulle eet, het Jesus brood geneem (kai ... labōn) en die seën gevra (eulogêsas). Daarna het Hy dit gebreek (eklasen) en vir hulle gegee (kaì edōken autoîs) met die woorde: Neem dit, dit is my liggaam (NAB; Mark 14:22).

Dit is baie waarskynlik dat die instellingswoorde van die nagmaal reeds vroeg in die vroeë kerk min of meer geyk geraak het. So 'n formule is by Paulus se verwysing na die instelling van die nagmaal sigbaar:

Die Here Jesus het in die nag waarin Hy oorgelewer is, brood geneem (elaben arton) en, nadat Hy God daarvoor gedank het (... kaì eucharistēsas ...), het Hy dit gebreek (eklasen) en gesê: 'Dit is my liggaam ...' (NAB; 1 Kor 11:23-24).

'n Vergelyking tussen Markus 6:41 en 8:6 (die onderskeidelike bewoording in die dubbel-vertelling) aan die een kant en Markus 14:22 en 1 Korintiërs 11:23-24 (die onderskeidelike bewoording in die Markaanse en Pauliniese weergawes van die instelling van die nagmaal) aan die ander kant, dui sonder die moontlikheid van teenspraak aan dat die konklusie hierbo reg was: Dit is nie Markus wat verantwoordelik was vir die verbandlegging tussen die broodvermeerderingsberigte en die nagmaalstradisie nie. Dit het reeds in die tradisieoorlewering vóór Markus bestaan. Hierdie konklusie word ook bevestig deur Johannes se verbandlegging tussen die vertelling oor die vermeerdering van brood (Joh 6:1-15), die toespeling op die Ou-Testamentiese vertelling oor die manna uit die hemel (Joh 6:22-40) en die nagmaalstradisie (Joh 6:41-59).

Die standpunt is gevolglik aanvaarbaar dat die twee afsonderlike 'wondervertellinge' oor die vermeerdering van brood (en vis) in onderskeidelik Markus 6:30-44 en 8:1-10 twee tradisies verteenwoordig van een en dieselfde Vorlage wat in verskillende Sitze im Leben verskillend gevorm is. 
Maar is die dubbel-vertelling in die Matteus- en Markusevangelies 'n 'wondervertelling' of 'n 'nagmaalstradisie'? Dit bring ons uit by die formgeschichtliche vraagstelling of die vertelling oor die vermeerdering van brood as 'n 'novelle' (Dibeliusse term) of as 'n nagmaalskategese beskou en dienooreenkomstig funksioneel verklaar moet word.

\subsection{Die vermeerdering van brood: Wondervertelling of nagmaalskategese?}

Ons het reeds daarop gewys dat die dubbel-vertelling oor die vermeerdering van brood (en visse?) nie die wonder as sodanig berig nie. Die wonder word wel sterk geïmpliseer. Die vertelling(e) bevat egter nie die kenmerkende detail en afronding van die tipiese wondervertelling ('novelle') in die evangelies nie (kyk Dibelius se kategorisering en beskrywing van kenmerke hierbo). Dit bevat ook nie 'n verwysing na 'n implisiete of eksplisiete hulproep in 'n noodsituasie nie en ook nie 'n beskrywing van die reaksie van òf die geaffekteerdes ò die omstanders nie (kyk Van Iersel 1964: 183). In al die parallelle kontekste in al vier evangelies pas dit ook nie dat die funksie van die vertelling kerugmaties-propagandisties met betrekking tot mededingende (Hellenistiese) wonderdoeners of gode sou wees nie. Daarenteen het dit uit ons bespreking hierbo geblyk dat die vertelling, soos sy Ou-Testamentiese parallel ten opsigte van die manna uit die hemel (kyk ook Deut 8:3 ten opsigte van die uittog uit Egipte/die viering van die Joodse pasga), in die vroeë kerk binne die raamwerk van die nagmaalstradisie geïnterpreteer is.

In sowel die Markus- as die Matteusevangelie het die dubbel-vertelling dus nie die wonderelement as sodanig in die oog nie en kan dit ook nie as 'n 'novelle' geklassifiseer word nie. In hierdie twee evangelies is dit eerder die geval dat die verhouding partikularisme-universalisme inhoudelik in fokus is. Reeds Origines en Augustinus het hierdie saak op 'n manier ingesien (kyk Boobyer 1953: 77). Hierdie verhouding het betrekking op die sendingverpligting van die vroeë kerk teenoor ook die heidene en nie net teenoor die Jode alleen nie. Volgens Pesch (1982: 17) is die opeenvolging van eers (partikulêre) Jodesending en dan (universele) heidensending een van die wesenlike vooronderstellinge van die vroeg-kerklike sending. Pesch sê die Jodesending was onproblematies en hy noem dit missio interna. Daarteenoor was die heidensending problematies en hy noem dit missio externa. Dit is myns insiens juis hierdie aangeleentheid wat die dubbele opname van die 
twee weergawes van dieselfde tradisie in die Markusevangelie en in die Matteusevangelie, wat Markus as belangrikste bron gebruik het, funksioneel maak. Die onderskeie tendense in die Lukas- en Johannesevangelie is egter anders (vgl Van Iersel 1964: 190-192 ten opsigte van Luk 9:12-17 en Schenke 1980 ten opsigte van Joh 6:26-58). Pesch se opmerking word bevestig deur Markus se redaksionele plasing van die dubbel-vertelling in die raamwerk van sy hele evangelie. Maar dit geld net wat Markus betref. In die volgende afdeling toon ons aan dat Matteus dié motief herinterpreteer en die verhouding partikularismeuniversalisme ooreenkomstig sy eie teologiese perspektief aangebied het. Vereers is ons geïnteresseerd in die kwessie oor hoe die betrokke vertelling binne die raamwerk van die nagmaalstradisie in opeenvolgende vroeg-kerklike oorleweringstadia moontlik gefunksioneer het.

Volgens Bultmann (1970: 232) het Markus 8:1-10 in 'n latere redaksionele fase ontstaan as Markus 6:35-44. In die eersgenoemde vertelling het Jesus self die inisiatief geneem om die aandag op die skare se honger te vestig, terwyl dit die dissipels in die laasgenoemde vertelling was. Markus 8:1-10 het ook meer toespeling op die nagmaal as Markus 6:35-44 en kom in besonderhede meer met 1 Korintiërs 11:24 ooreen (Jeremias 1960: 178-181). Van Iersel (1964: 184 en 186) meen dat die eerste vertelling in 'n Joods-Christelike situasie gevorm is en die tweede in ' $n$ heiden-Christelike.

Hierdie standpunt dat die dubbel-vertelling in twee onderskeie tradisiekringe apart gevorm is, word deur die siening van Friedrich (1964: 14-19) onderbou. Volgens hom is die herderstematiek die Leitmotiv van die eerste vertelling wat ook 'n Moses-Messias-tipologie laat deurskemer. Afgesien van die Ou-Testamentiese toespeling (Ps 23:2) in die Jesus-woord, 'Kom ... na 'n stil plek toe en rus 'n bietjie' (Mark 6:31), en die verwysing na 'groen gras' (Mark 6:39) (Van Iersel 1964: 188), is die herdersmotief ook in Markus 6:34 duidelik merkbaar:

Toe Jesus uit die skuit klim, het Hy 'n groot menigte mense daar gesien en Hy het hulle innig jammer gekry, want hulle was soos skape wat nie 'n wagter het nie. Hy het hulle toe baie uitvoerig begin leer (NAB; my beklemtoning).

Hierdie vertelling oor die voed van die skare deur Jesus in 'n 'afgeleë plek' (erēmon tópon - Mark 6:31) herinner volgens Friedrich aan 'n Moses wat die skare in die woestyn gevoed het. Jesus as die 'nuwe Moses' voed die skare in die messiaans-eskatologiese maaltyd. 
Van Iersel (1964: 188 en 189) meen dat die 'eskatologiese maaltyd'motief wel in die betrokke vertelling aanwesig is, maar dat dit vir Markus veel eerder gaan om die gelykberegtiging van Jode en heidene aan die maaltyd (nagmaal) van die Here. Dit kan myns insiens ook gesien word in die topografiese oorgang van die partikulêre gerigtheid op vyfduisend (Joodse) mans, aan die westelike kant van die See van Galilea oorkant Betsaida (Mark 6:45), na die universele gerigtheid op vierduisend (heiden-)mans in die gebied van Dekapolis (Mark 7:31). Hierdie oorgang van 'n partikulêre gerigtheid na ' $n$ universele blyk hoogs waarskynlik ook uit die getal mandjies wat respektiewelik volgemaak is met stukke wat oorgebly het, naamlik twaalf teenoor sewe. Hierbenewens kom daar tussen die twee voedberigte die vertelling oor die (heidense) Siro-Fenisiese vrou voor wat ook gevoed word, soos hondjies wat die kindertjies se 'oorskiet brood' onder die tafel eet (Mark 6:24-30). Die berig dat dit die (partikulêr-gerigte) dissipels was wat in die eerste van die dubbel-vertelling die inisiatief neem, terwyl dit die (universeel-gerigte) Jesus was wat dit in die tweede vertelling doen, kry sodoende reliëf.

Volgens Van lersel (1964: 180-181) is die Sitz im Leben van die vertelling die vroeg-kerklike kategese en dan in die besonder binne die raamwerk van die nagmaal wat op daardie stadium nog nie van gewone maaltye geskei was nie (kyk ook Gerhardsson 1979: 57). Die kategese-element is veral in Markus 6:34 en 8:17-21 sigbaar. Verder is dit opvallend dat die dissipels so ' $n$ prominente en buitengewone rol vervul (kyk Mark 6:41 en 8:6). In die tipiese wondervertellinge word die dissipels maar net enkele kere vermeld (Held 1961: 171; Gerhardsson 1979: 54). Hier, net soos die vertelling oor die seewandeling, is dit nie die geval nie. Van Iersel (1964: 181) koppel die 'vermittelnde Rolle der Jünger bei der Verteilung der Brote an die Menge' met die 'vermittelnde Rolle der Amtsträger bei der Abendmahlfeier.'

Die vertelling oor die vermeerdering van brood is dus, formgeschichtlich gesien, nie 'n 'novelle' nie, maar 'nagmaalskategese'. Die Sitz im Leben is: Enersyds die nagmaal (Mark 6:41 en 8:6) en die hele gemeente se deelhê aan die tafelgemeenskap (Mark 6:42a). Andersyds die intermediêre funksie van ampsdraers by die nagmaalsviering (Van Iersel 1964: 182). Traditionsgeschichtlich gesien, het die vertelling waarskynlik in sowel die Joods-Christelike as die heiden-Christelike tradisiekringe ontstaan: In die Joods-Christelike tradisiekring is die wonderelement afgeskaal deur die integrasie van sowel die herders- as die nagmaalsmotief daarmee. In die heiden-Christelike tradisiekring word 
dit nog verder op die nagmaalsviering, waaraan Helleniste naas Jode deel het, betrek (Van Iersel 1964: 189-190).

\section{MATTEUS 14:13-21 (EN PARALLELLE DELE) EN DIE REDAKTIONSGESCHICHTE}

\subsection{Wat is Redaktionsgeschichte?}

'n Ernstige leemte in die formgeschictliche teksinterpretasie is dat die hermeneutiese belang van die holistiese konteks nie genoegsaam benut was nie. Met die opkoms van die Redaktionsgeschichte het die visie binne die histories-kritiese paradigma wel vorendag gekom dat 'n evangelis meer is as net ' $n$ versamelaar van oorgelewerde tradisies. Die evangeliste is in die begin gesien as vroeg-kerklike 'teoloë', uiteraard nie in die sin wat die 'teologie' sedert die Middeleeuse skolastiek as wetenskap beoefen is nie. 'n Evangelie, soos dit voor ons lê, is 'n eindproduk van 'n oorleweringsproses waarin die evangelis as 'teoloog' die tradisies redaksioneel verwerk het. Deur 'n historiese analise van hierdie redigeringsaktiwiteit lei die redaktionsgeschichtliche eksegeet die teologiese intensie van die skrywer-redaktor af. Waar die Formgeschichte 'n mikro-vorm, soos byvoorbeeld 'n wondervertelling, met betrekking tot sy Sitz im Leben in die vroeë kerk interpreteer, daar verklaar die Redaktionsgeschichte die holistiese teks as makro-vorm met betrekking tot die Sitz im Leben Ecclesiae. Daar word met laasgenoemde term verwys na die spesifieke vroeg-kerklike gemeentekring waarvoor en van waaruit die evangelies as vertolker van 'n bepaalde 'teologie' skryf. Dis met ander woorde die derde kontekstualiseringsvlak waarvan ons vroeër (afdeling 3.1) gepraat het.

Die Redaktionsgeschichte is dus nie denkbaar sonder die insette van ander metodiese fasette van die historiese kritiek nie. Dit word gekruisstut deur die resultate van die Formgeschichte en veral dié van die Literarkritik en die Traditionsgeschichte. In kontinuïteit met die Literarkritik, deur van die twee bronne-teorie uit te gaan, en in kontinuiteit met die Form- en Traditionsgeschichte, deur te konsentreer op die Sitz im Leben Ecclesiae, word die teologiese intensie van 'n evangelis uit die redaksie-plus-tradisie en die redaksie-minus-tradisie afgelees. Die Markusevangelie word in hierdie proses as belangrik beskou, omdat Matteus en Lukas hulle onderskeie redaksionele arbeid binne die raamwerk van die Markusevangelie verrig het. Dit is soos Crossan (1978: 53) dit by wyse van vraag en antwoord stel: 
What happened to (the) Markan form/content ...? What happened, for me, was Matthew and Luke and John ... . For what Mark did, genetically to Matthew and Luke and how I do not know to John, was to trap them within his form with a content they could not accept, to seduce them within his structure with a substance they could not share.

Wat die redaktionsgeschichtliche eksegese van die Markusevangelie self betref, is die proses ingewikkelder, aangesien daar onsekerheid bestaan ten opsigte van die voor-Markaanse tradisie. Om die probleem te help oplos, word daar benewens die ondersoek van moontlike redaksionele verwerking van veronderstelde voor-Markaanse tradisies (bv Mark 4:1-34; Mark 2:1-3:6; 11:27-12:40 en Mark 14-15 - kyk Pesch 1977:20-21), ook klem gelê op sekere teksinterne besonderhede soos die unieke aanvang en slot van diskoerse, en die verandering in bewoording en in die orde van literêre eenhede.

\subsection{Die Sitz im Leben Ecclesiae van die Matteusevangelie}

Die form- en traditionsgeschichtliche ondersoek van die dubbel-vertelling in die Markusevangelie oor die vermeerdering van brood het die volgende resultate gelewer:

* Die eerste vertelling is waarskynlik in 'n Joods-Christelike situasie gevorm en die tweede in 'n Hellenisties-Christelike.

* Die eerste vertelling is waarskynlik van toepassing gemaak op die voed van 'n Joodse skare, terwyl die tweede van toepassing gemaak is op 'n universele skare.

* Markus het redaksioneel die twee vertellinge met mekaar verbind. Enersyds het $\mathrm{Hy}$ dit gedoen deur die vertelling oor die heidense Siro-Fenisiese vrou wat eet van die 'oorskiet brood' wat aanvanklik vir die Jode bedoel is, tussen die twee vertellinge te plaas. Andersyds het $\mathrm{Hy}$ dit gedoen deur die vorm 'nagmaalskategese' funksioneel aan te wend en die intermediêre dissipels/ampsdraers tot universele sendingbetrokkenheid op te roep.

Wat het die redaktor van die Matteusevangelie vanuit die perspektief van sy besondere Sitz im Leben Ecclesiae met hierdie Markaanse besonderhede gemaak? Beide motiewe wat in die Markaanse aanbieding 
prominent is, word deur Matteus opgeneem en herinterpreteer. Dit is naamlik die verhouding partikularisme-universalisme en die bepaalde dissipelbeeld.

Wat die dissipelbeeld betref, wysig Matteus die Markaanse beeld. Die dissipels in die Markusevangelie het 'n onvermoë om te verstaan wie Jesus werklik is en wat die wil van God (en van Jesus) is (vgl o a Best 1977: 387-388). Aan die een kant het die dissipels in die Matteusevangelie volledige insig in die aard van Jesus se persoon en werk. Hulle funksie hou verband met hulle profete-sendingtaak (kyk o a Matt 10:40-42). Aan die ander kant openbaar die dissipels, ten spyte van hulle volledige insig, 'n kleingeloof-geneigdheid. Hierdie geneigdheid veroorsaak dat hulle dikwels met 'n perspektief vorendag kom wat ooreenkoms toon met dié van die Joodse leiers. Hierdie dreigende gemeenskaplikheid tussen die Joodse leiers en die dissipels hou verband met ' $n$ ongehoorsaamheid om die wil van God na sy ware bedoeling aan en met betrekking tot die (Joodse) volk (= laós/ochloi/próbata) te verkondig en uit te leef (kyk veral Matt 7:15-20 waar die term 'skape'/tà próbata in vs 15 gebruik word) (Van Aarde 1982a: 87-97).

Wat die verhouding partikularisme-universalisme betref, Matteus wysig die Markaanse sendinggerigtheid. Hierdie gerigtheid in die Markusevangelie word gekenmerk deur die opeenvolging van eers 'n partikulêr-Joodse gerigtheid en dan 'n universeel-heidense gerigtheid. Dit word deur Matteus herinterpreteer en in iets byna die omgekeerde verander. Frankemölle (1982: 125) som hierdie herinterpretasie soos volg op: 'Zwischen missio interna und missio externa besteht nicht ein zeitliches Nacheinander, sondern eine Wechselbeziehung ....' Matteus se hantering van die verhouding partikularisme-universalisme hang ten nouste saam met sy besondere Sitz im Leben Ecclesiae. Die situasie in die vroeë kerk waarop die Matteusevangelie betrekking gehad het, is hoogs waarskynlik deur die breuk tussen die sinagoge en die kerk bepaal (kyk o a Hummel 1966 en Künzel 1978). In so 'n situasie was 'n aangeleentheid soos die heidensending nie meer 'n strydkwessie nie. Die basiese probleem wat in Matteus se gemeentesituasie asanwesig was - hoe moeilik rekonstrueerbaar dit ook al en hoe ontbrekend die besonderhede ook al is - was die gevaar dat die 'kerklike ampsdraers' te midde van die alledaagse heidensending die arm, noodlydende 'kerkvolk' verwaarloos en verontagsaam het. Hierdie 'kerkvolk' was in hoofsaak Joodse Christene op die Siriese platteland. Dié toedrag van sake moet waarskynlik toegeskryf word aan die skeiding tussen die Joodse sinagoge en die Christelike kerk. Die vervolging van die kant 
van die herorganiseerde Joodse leiers te Jamnia het vermoedelik daartoe bygedra dat daar in die gemeente 'n onvergeeflike en liefdelose gesindheid geheers het teen die Jood, en sy voorgeslag (vgl Matt 27:25), wat Jesus by die kruisiging godslasterend verwerp het. Soos die voorpase Jesus, te midde van sý sending in Galilea van die heidene (kyk Matt 4:15 en 15:29 in onderskeid van Mark 7:31), na die Joodse skare omgesien het, terwyl die heidene nie daarvan uitgesluit was nie, só behoort die na-pase 'kerklike ampsdraers', as die verlengstuk van die dissipels, in ' $n$ alledaagse heidensendingsituasie nie die noodlydende 'kerkvolk' te verontagsaam nie. Hierdie 'noodlydendes' word in die Matteusevangelie deur middel van benaminge soos onder andere 'geringstes'/hoi elàchistoi (o a Matt 25:40,45) en 'kleintjies'/hoi mikroí (o a Matt 18:14), 'skape'/tà próbata (o a Matt 18:12), 'kindertjies'/tà paidía (o a Matt 18:3) en 'kinders'/tà tékna (o a Matt 15:26) (vgl Van Aarde 1982a: 91-93).

Die bepaalde Matteaanse dissipelbeeld wat onder andere vanuit die Markaanse aanbieding van die dubbel-vertelling oor die vermeerdering van brood oorgeneem en herinterpreteer is, het dus ten nouste betrekking op die verhouding partikularisme-universalisme in die Matteusevangelie.

\subsection{Matteaanse redaksie}

Held (1961: 171-177) het 'n volledige studie gemaak van die Matteaanse redaksie van die onderhawige dubbel-vertelling in die Markusevangelie. Sy studie gaan in op besonderhede. Samevattend staan twee sake uit: Eerstens, die vermeerdering en deurgee van visse aan die skare is aansienlik deur Matteus gerelativeer (vgl Matt 14:19 en 15:36 met Mark 6:41 en 8:7 resp). Tweedens die rol van die dissipels is sonder twyfel in 'n besliste intermediêre funksie ontwikkel. Laasgenoemde redaksionele wysiging is baie prominent:

Daarna het Hy die brood gebreek en dit vir sy dissipels gegee om aan die mense voor te sit (Mark 6:41).

Hy het (die brood) gebreek en dit vir sy dissipels gegee om uit te deel ... (Mark 8:7).

Daarna het $\mathrm{Hy}$ die brood gebreek en dit aan sy dissipels gegee, en hulle het dit aan die mense gegee (Matt 14:19).

Daarna het Hy die brood gebreek en dit aan sy dissipels gegee, en hulle het dit aan die mense gegee (Matt 15:36). 
Die relativering van die uitdeel en deurgee van visse in die maaltyd word deur Held (1961: 176) en Van Iersel (1964: 193) só geïnterpreteer dat Matteus daarmee die nagmaalskarakter van die maaltyd sterker as Markus sou beklemtoon het. Hierdie interpretasie is egter onwaarskynlik. Vis het 'n belangrike rol in die vroeg-Christelike nagmaalsimboliek gespeel. In heelwat vroeg-Christelike wandskilderings in katakombes kom brood èn vis as simbole van die nagmaal voor (kyk Richardson 1955: 149). Matteus se relativering van die rol van die vis in die dubbelvertelling het waarskynlik dus nie die beklemtoning van die nagmaalsmotief in die oog nie. Dit beteken egter nie dat die geykte nagmaalsterminologie in die dubbel-vertelling deur Matteus verwyder is of dat hy nie die instelling van die nagmaal oorvertel het nie (kyk Matt 26:26-29). Wat wel in die Matteusevangelie gebeur, is dat die kategetiese element in die dubbel-vertelling afgeskaal word. Matteus benadruk 'n messiaans-eskatologiese maaltyd-motief (vgl ook Matt $22: 1-14 ; 25: 31-46$ en $26: 29$ ). Hierdie afskaling kan ook gesien word in die feit dat Matteus die verwysing in Markus 6:34 dat Jesus die skare 'uitvoerig geleer' het, nie oorgeneem het nie (kyk ook Ellis 1974: 66 nota 75).

Die feit dat Matteus die kategetiese element in die dubbel-vertelling afskaal, kan miskien verband hou met die struktuur van sy holistiese konteks en die verskynsel dat hy hoofsaaklik in lang Jesus-diskoerse die dissipels as die objek van Jesus se kategeses maak. In die Matteusevangelie word vyf groot kategetiese diskoerse met mikrovertellinge afgewissel. Die dubbel-vertelling oor die vermeerdering van brood is nie in een van hierdie kategetiese diskoerse opgeneem nie, maar wel in die vierde mikrovertelling, naamlik Matteus 13:53-17:27 (kyk Van Aarde 1982b). In hierdie besondere mikrovertelling word die bepaalde Matteaanse dissipelbeeld en die wisselwerking tussen universele en partikulère sending op 'n merkwaardige wyse deur die deurgee van brood aan die Joodse skare geilllustreer.

Held (1961: 172-174) het baie netjies aangetoon hoedat Matteus die besondere Markaanse dissipelbeeld ooreenkomstig sy eie teologiese perspektief in die dubbel-vertelling gewysig het. Matteus (en Lukas) het die kru (sarkastiese?) reaksie van die dissipels op Jesus se opdrag om die skare kos te gee, weggelaat:

Hulle antwoord Hom: 'Moet ons met twee honderd mense se dagloon brood gaan koop om vir hulle iets te ete te gee?' (Mark 6:37). 
Klostermann (1971: 129) het hierdie reaksie as 'n 'unpassende Frage' en 'n 'dreiste Gegenfrage' beskryf. Dit kom ooreen met die tipiese Markaanse beeld van die dissipels wat gebrek aan insig het:

Sie zeigt das völlige Unverständnis der Jünger nicht allein gegenüber der Person und der Sendung ihres Herrn, sondern auch gegenüber ihrer Beauftragung durch ihn (Held 1961: 172).

Hierdie onbegrip ten opsigte van hulle eie taak is veral af te lei uit die feit dat hulle die sleutelwoorde in Jesus se opdrag, 'gee vir die skare iets te ete', weer in hulle eie onvanpaste teenvraag opneem.

Matteus maak dit egter baie duidelik dat die dissipels volgens sy perspektief nie meen om self kos vir die mense in die omtrek se dorpies te gaan koop nie. Dit gaan by die dissipels eerder om die kommer dat hulle te min kos by hulle het:

Hulle sê toe vir Hom: 'Ons het hier net vyf brode en twee vissies (Matt 14:17; my beklemtoning).

Die dissipels het dus insig in wat Jesus se opdrag behels, 'führen aber seinen Auftrag nicht gehorsam aus, sondern weisen - offenbar kleingläubig - auf ihre geringen Vorräte hin' (Held 1961: 173).

Die insig van die dissipels asmede hulle kleingeloof hou in die Sitz im Leben Ecclesiae van die Matteusevangelie hoogs waarskynlik verband met die dissipels/kerklike ampsdraers se geneigdheid om, teen die agtergrond van die (universele) heidensending, die (partikulêre) Jodesending te verontagsaam. Indien dit gebeur, maak die dissipels/kerklike ampsdraers gemene saak met die Joodse lejers. Laasgenoemde het juis vanweë hulle formalistiese godsdiensbeoefening nie 'n oog en 'n hart vir die 'verlore skape van Israel sonder ' $n$ herder' gehad nie.

Hierdie aspek van Matteus se 'teologie' is reeds vroeër deur my in 'n ander artikel beredeneer (Van Aarde 1982b). In die besonder kan gewys word op Matteus se betekenisvolle verbandlegging tussen die dubbelvertelling oor die vermeerdering van brood en die vertelling oor die gevaar van die suurdeeg (van die brood) van die leer van die Joodse leiers (Matt 16:1-12). Die 'brood' van die Joodse leiers staan in skerp kontras met dié wat Jesus deur middel van sy dissipels vir die Joodse skare (en die heidene) aangebied het. Teenoor die 'brood' wat Jesus gee, is die 'brood' van die Joodse leiers verderflike formalisme sonder liefde. Dis teen hierdie formalistiese perspektief waarteen die dis- 
sipels/kerklike ampsdraers gemaan word. Die Matteaanse redaksie van Markus se dissipelbeeld en sy aanbieding van die verhouding partikularisme-universalisme het dus duidelik en effektief neerslag gevind in sy oorvertel van die dubbel-vertelling oor die vermeerdering van brood.

\section{NABETRAGTING}

Sonder om die reeds bespreekte waarde en tekortkominge van die historiese kritiek verder in die lig van bostaande ondersoek te voer, kan die volgende stelling oor die historiese kritiek gemaak word: Die aard van die Bybel as Heilige Skrif/Woord van God en die waarheid daarvan is nie deur die studie aangetas nie. Dogma-bedreiging en geloof-vyandigheid het nie elemente uitgemaak van ò die eksegetiese proses ò die resultate daarvan nie. Wat wel gebeur het, is dat sekere antwoorde op bepaalde eksegetiese vrae gegee is. As resultaat het die rykdom in die verskeidenheid van die Bybelse boodskap vorendag gekom. En niks verhinder dat hierdie resultaat positief in geloofsverantwoordende vraagstellings rakende dogma-interpretasie en dogmavorming benut word nie.

\section{Literatuurverwysings}

BEST, E 1977. The role of the disciples in Mark. NTS 23, 377-401.

BETZ, O \& GRIMM, W 1977. Wesen und Wirklichkeit der Wunder Jesu: Heilungen - Rettungen - Zeichen - Aufleuchtungen. Frankfurt a M: Peter Lang.

BOERS, H 1979. What is New Testament theology? The rise of criticism and the problem of a theology of the New Testament. Philadelphia: Fortress.

BOOBYER, GH 1953. The miracles of the loaves and the gentiles in St Mark's gospel. SITh 6, 77-87.

BULTMANN, R 1970. Die Geschichte der synoptischen Tradition. 8. Aufl. Göttingen: Vandenhoeck.

CROSSAN, JD 1978. A form for absence: The Markan creation of gospel. Semeia 12, 41-55.

CULPEPPER, RA 1984. Story and history in the gospels. RExp 81, 456-478.

DEIST, FE 1984. ' $n$ Kritiese evaluering van die kritiek van FN Lion-Cachet. In die Skriflig $18 / 72,47-56$.

DE JONGE, M 1982. De historisch-kritische methode, in Klijn 1982: 71-85.

DIBELIUS, M 1959. Die Formgeschichte des Evangeliums. 3. Aufl. Hrsg von G Bornkamm. Tübingen: Mohr.

EBELING, G 1981. The Bible as a document of the university, in Betz, HD (ed), The Bible as a document of the university, 5-23. Chico: Scholars Press. 
ELLIS, PF 1974. Matthew: His mind and his message. Collegeville: The Liturgical Press.

FRANKEMÖLLE, H 1982. Zur Theologie der Mission im Matthäusevangelium, in Kertelge 1982: 93-129.

FRIEDRICH, G 1964. Die beiden Erzählungen von der Speisung in Mark vi 31-44, viii 1-9. ThZ 20, 10-22.

FRYE, RM 1971. A literary perspective for the criticism of the gospels, in Miller, DG \& Hadidian, DY (ed), Jesus and man's hope, 193-221. Pittsburgh: Pittsburgh Theological Seminary.

FRYER, NSL 1984. The freedom of the exegesis. NGTT 25, 260-269.

FRYER, NSL [1986]. The historical critical method: Yes or no? Scriptura. (Forthcoming).

FUNK, $R$ 1966. Language, hermeneutic and word of God: The problem of language in the New Testament and contemporary theology. New York: Harper \& Row.

GERHARDSSON, B 1979. The mighty acts of Jesus according to Matthew. Lund: CWK Gleerup.

HELD, HJ 1961. Matthäus als Interpret der Wundergeschichten, in Bornkamm, G, Barth, G \& Held, HJ, Überlieferung und Auslegung im Matthäusevangelium, 155-287. 2. Aufl. Neukirchen: Neukirchener Verlag. (Wissenschaftliche Monographien zum Alten und Neuen Testament.)

HUMMEL R 1966. Die Auseinandersetzung zwischen Kirche und Judentum im Matthäusevangelium. München: Kaiser.

JEREMIAS, J 1960. Die Abendmahlsworte Jesu. 3. Aufl. Göttingen: Vandenhoeck.

KERTELGE, K (Hrsg) 1982. Mission im Neuen Testament. Freiburg: Herder. (Quaestiones Disputatae 93.)

KLIJN, AFJ (red) 1982. Inleiding tot de studie van het Nieuwe Testament. Kampen: Kok.

KINGSBURY, JD 1975. The historical-critical method in perspective. Currents in Theology and Mission 2, 132-141.

KLOSTERMANN, E 1971. Das Matthäusevangelium. 4. Aufl. Tübingen: Mohr. (Handbuch zum Neuen Testament.)

KRENTZ, E 1975. The historical-critical method. Philadelphia: Fortress.

KÜNG, H 1980. Does God exist? An answer for today. Translated by E Quinn. London: Collins.

KÜNZEL, G 1978. Studien zum Gemeindeverständnis der Matthäus-Evangeliums. Stuttgart: Calwer.

LATEGAN, BC 1982. Inleiding tot de uitlegging van het Nieuwe Testament, in Klijn 1982: 47-70.

LÜHRMANN, D 1984. Auslegung des Neuen Testaments. Zürich: Theologischer Verlag. (Zürcher Grundrissen zur Bibel.)

MONTAGUE, GT 1979. Hermeneutics and the teaching of Scripture. CBQ 41, 1-17.

PESCH, R 1977. Das Markusevangelium. 1. Teil: Einleitung und Kommentar zur Kap. 1-8, 26. Freiburg: Herder. (Herders Theologischer Kommentar zum Neuen Testament.)

PESCH, R 1982. Voraussetzungen und Anfange der urchristlichen Mission, in Kertelge 1982: 11-70.

RICHARDSON, A 1955. The feeding of the five thousand: Mark 6:34-44. Interp 9, $144-149$.

SCHENKE, L 1980. Die formale und gedankliche Struktur von Joh 6, 26-58. BZ 24, $21-41$.

SCHMIDT, KL 1969. Der Rahmen der Geschichte Jesu: Literarkritische Untersuchungen zur ältesten Jesusüberlieferung. 2. Nachdruck. Darmstadt: Wissenschaftliche Buchgesellschaft.

SCHNELL, CW [1986]. Die sinoptiese tradisie as bron van historiese kennis oor Jesus van Nasaret en sy eerste volgelinge. Ongepubliseerde voordrag gelewer voor die NTWSAsubgroep, LiVTRed-Pretoria, 13 Februarie 1986.

SCHWEITZER, A 1951. Geschichte der Leben-Jesu-Forschung. 6. Aufl. Tübingen: Mohr. 
STUHLMACHER, P 1979. Vom Verstehen des Neuen Testaments: Eine Hermeneutik. Göttingen: Vandenhoeck.

THEISSEN, G 1974. Urchristliche Wundergeschichten: Ein Beitrag zur formgeschichtliche Erforschung der synoptischen Evangelien. Gütersloh: Gütersloher Verlagshaus. (StNT 8.)

TUCKER, GM 1975. Editor's forword, in Krentz 1975: v-vi.

VAN AARDE, AG 1982a. God met ons: Dié teologiese perspektief van die Matteusevangelie. DD-proefskrif, Universiteit van Pretoria.

VAN AARDE, AG 1982b. Matthew's portrayal of the disciples and the structure of Matthew 13:53-17:27. Neotestamentica 16, 21-34.

VAN AARDE, AG 1985. Skrifgebruik: Hermeneutiese riglyne. HTS 41, 547-578.

VAN HUYSSTEEN, JWV 1986. Teologie as kritiese geloofsverantwoording: Teorievorming in die sistematiese teologie. Pretoria: RGN. (RGN-Studies in Navorsingsmetodologie 2.)

VAN IERSEL, B 1964. Die wunderbare Speisung und das Abendmahl in der synoptischen Tradition (Mk vi 35-44 par, viii 1-20 par). NT 7, 167-194.

VORSTER, WS 1982. 'Formgeschichte' en 'Redaktionsgeschichte', in Klijn 1982: 94-111.

ZORN, RO 1984. Hermeneutics: Old and new? Vox Reformata 42, 10-19. 